\title{
Phytochemical Evaluation and Anti-Inflammatory Activity of Ethanolic Extract of Calotropis procera Leaves
}

\author{
Naveed Aslam Dogar1,*, M. Hamza Shahid ${ }^{1}$, Hafiz Usama Shaukat', M. Abubakar Khan¹, Farooq Saleem ${ }^{1,2}$ \\ ${ }_{1}^{1}$ Department of Chemistry, Government College of Science, Lahore, Pakistan \\ 2Faculty of Pharmacy, University of Lahore, Pakistan
}

\begin{abstract}
Background: Medicinal plants have been used for centuries to cure various diseases. There is a huge potential to investigate the medicinal impacts of different parts of plants. Roots, stem, leaves and fruits of Calotropis procera are known for their biological activities. Calotropis procera plant shows multiple pharmacological activities like anti-cancer, anti-microbial, antioxidant, antimalarial, hepatoprotective and anti-diabetic activities.

Objectives: The objective of the current research was ethanolic extraction of Calotropis procera leaves and to study phytochemistry and anti-inflammatory activity.

Methodology: In this study, we used the extract of Calotropis procera leaves for detection of phytochemicals and anti-inflammatory activity in vitro by hypotonicity induced hemolysis on $2 \% \mathrm{HRBC}$ suspension, using UV-Vis spectrophotometer.

Results: Phytochemicals like alkaloids, terpenoids, and flavonoids were present in large amount while tannins, saponins, steroids and cardiac glycosides were in small amount, whereas phlobatannins and anthraquinone were not detected. The potential of the ethanolic extract of Calotropis procera leaves was compared with Diclofenac sodium $(100 \mu \mathrm{l} / \mathrm{ml}, 200 \mu \mathrm{l} / \mathrm{ml})$. The leaves extract of Calotropis procera $(100,200,300,400,500 \mu / / m l ~ e a c h)$ showed significant anti-inflammatory activity by hypotonicity induced hemolysis on $2 \%$ HRBC suspension.

Conclusion: The Calotropis procera leaves have the potential to cure inflammatory diseases and can be used as anti-inflammatory medicine and analgesic.
\end{abstract}

Keywords

Anti-inflammatory activity, Calotropis

procera leaves, phytochemical evaluation,

antioxidant, HRBC suspension, UV-Vis

spectrophotometer

Cite this article: Dogar NA, Shahid MH, Shaukat HU, Khan MA, Saleem F. Phytochemical Evaluation and Anti-Inflammatory Activity of Ethanolic Extract of Calotropis procera Leaves. RADS J Biol Res Appl Sci. 2020; 11(1):47-52.

This is an Open Access article distributed under the terms of the Creative Commons Attribution License (http://creativecommons.org/licenses/by/4.0), which permits unrestricted use, distribution, and reproduction in any medium, provided the original work is properly cited.

\section{INTRODUCTION}

Anciently, men used herbal medicines for curing various diseases. Pharmacology expands rapidly with the advancement of scientific knowledge. These plant-based medicines are safe and easily available 1 . Traditional systems such as Hikmat, Ayurveda, Unani, Siddha and homoeopathy suggested $95 \%$ different medicinal plants in
Article info.

Received: September 14, 2019

Accepted: July 26, 2020

Funding Source: Nil

Conflict of Interest: Nil the treatments ${ }^{2}$. World Health Organization (WHO) claimed that $60-80 \%$ population of this world use ancient medicinal remedies for common diseases based on plants ${ }^{3}$. Calotropis procera is a medicinal plant of the family Asclepiadaceae. It is widely found in areas of Africa and Asia ${ }^{4}$. Calotropis procera name in other languages ${ }^{5}$ is 
shown in Table 1. The botanical name and other taxonomical data ${ }^{6}$ of Calotropis procera is shown in Table 2.

Calotropis procera is found in Pakistan, India, Afghanistan, Nepal, Iran, Algeria, Kenya, Nigeria, Niger, Oman, U.A.E, Saudi Arabia, Yemen, Vietnam and Zimbabwe ${ }^{6,7}$. In Pakistan, Calotropis procera grows almost in all parts of Pakistan as a shrub in plain, sandy, and alkaline lands ${ }^{8}$. Morphologically, it is a much-branched, erect small treelike structure of about $5.4 \mathrm{~m}$ height with milky latex throughout. The bark is soft and corky. Leaves are subsessile, opposite, oblong, thick, and green colored. Flowers are umbellate, cymes and tomentose on young 9 .

Table 1. Vernacular Names of Calotropis procera.

\begin{tabular}{ccc}
\hline S.No. & Language & Name \\
\hline 01 & Hindi & Madar \\
\hline 02 & English & Crown flower \\
\hline 03 & Bengali & Akanda \\
\hline 04 & Sanskrit & Adityapuspikar \\
\hline 05 & Punjabi & Aak, Ak \\
\hline
\end{tabular}

Table 2. Classification of Calotropis procera.

\begin{tabular}{|c|c|c|}
\hline S.No. & Kingdom & Plantae \\
\hline 01 & Division & Magnoliophyta \\
\hline 02 & Class & Magnoliopsida \\
\hline 03 & Subclass & Asteridae \\
\hline 04 & Order & Gentianales \\
\hline 05 & Family & Asclepiadaceae \\
\hline 06 & Subfamily & Caesalpinioideae \\
\hline 07 & Genus & Calotropis \\
\hline 08 & Species & Procera \\
\hline
\end{tabular}

Traditionally, different parts of the Calotropis procera have been used for ailments and are still utilized for the said purpose. For instance, latex has been used as a woundhealing agent and abortifacient in folk medicines ${ }^{10}$. Roots are used for eczema, leprosy, elephantiasis, asthma, cough and rheumatism ${ }^{11}$. Flowers use as anti-dandruff, also used in cholera and dysentery ${ }^{12}$. Leaves are used against swelling, joints pain, sores, skin diseases, rheumatic joints, snake bite, scabies, veterinary medicine, boils, anti-lice and scorpion stings 13,14,15.

Pharmacologically, Calotropis procera is used for many activities for e.g. dry latex shows anti-diabetic activity ${ }^{16}$, and Calotropis procera flowers are used for potent hepatoprotective agent against induced hepatic injuries ${ }^{17}$. Calotropis procera roots show anti-tumor activity ${ }^{18}$, while leaves extract show anti-microbial ${ }^{19}$ as well as antioxidant activity ${ }^{20}$. Likewise, the ethanolic extract of Calotropis procera leaves significantly exhibited the anti-malarial activity 21,22 .

Therefore, the present study is to find how much the leaves of Calotropis procera depicts the anti-inflammatory activity.

\section{MATERIALS AND METHODS}

\section{Collection of Plant Material}

The mature leaves of Calotropis procera were collected from the roadside in the area of sabzazar scheme Multan road, district Lahore, Punjab. All the leaves were washed well to eliminate all the dust, then dried in shade for 10 days. After that, the leaves were crushed with a grinder to make pieces as small as possible.

\section{Preparation of Plant Extract}

The known amount $(50 \mathrm{~g})$ of dried leaves of Calotropis procera were subjected to Soxhlet apparatus to get extract using ethanol $(250 \mathrm{ml})$ as a solvent. After two days, the obtained extract was evaporated by putting it in the oven and finally, the crude green colored semi-solid extract was obtained.

\section{Phytochemical Evaluation of Plant Extract}

Qualitative evaluation of phytochemicals in ethanolic extract of Calotropis procera leaves was done by dissolving a small amount of extract in ethanol ${ }^{23}$, and used further for the following detections: 


\section{Tannins}

Leaves extract $(1 \mathrm{ml})$ was mixed with $\mathrm{FeCl}_{3}(5 \mathrm{ml})$ solution, giving a dark green color which confirmed the presence of tannins ${ }^{24}$.

\section{Flavonoids}

Approx. $2 \mathrm{ml}$ of leaves' extract was mixed with $1 \mathrm{ml}$ of $\mathrm{NaOH}$ solution giving yellow color at first, which disappeared besides of solution of acid ${ }^{23}$, confirming the presence of flavonoids in the leaf extract.

\section{Alkaloids}

\section{Hager's test:}

A small amount (1-2ml) of leaves' extract was mixed with Hager's reagent and observed for yellow coloration ${ }^{23}$.

\section{Cardiac Glycosides:}

Approx. $2 \mathrm{ml}$ mixture of leaves' extract was mixed with $5 \mathrm{ml}$ of water, and $2 \mathrm{ml}$ of glacial acetic acid containing one drop of $\mathrm{FeCl}_{3}$ solution. After that, $1 \mathrm{ml}$ of conc. $\mathrm{H}_{2} \mathrm{SO}_{4}$ was added resulting in the formation of a brownish ring, thus indicating deoxy sugar characteristics of cardenoloids ${ }^{25}$.

\section{Saponins}

\section{Froth test:}

Approx. $1 \mathrm{ml}$ of leaves' extract was shaken with $5-10 \mathrm{ml}$ of water resulting in the stable froth, thus indicating the presence of saponins ${ }^{25}$.

\section{Phlobatannins}

A small amount of extract was boiled with $1 \% \mathrm{HCl}$, causing deposition of a red precipitate, hence, confirmed the presence of phlobatannins ${ }^{25}$.

\section{Steroids}

\section{Salkowaski Test}

Leaves extract $(1 \mathrm{ml})$ was mixed with $2 \mathrm{ml}$ of chloroform and $2 \mathrm{ml}$ of conc. $\mathrm{H}_{2} \mathrm{SO}_{4}$, forming red coloration in the chloroform layer and greenish-yellow in an acid layer, hence, confirmed the presence of steroids in the extracts ${ }^{23}$.

\section{Terpenoids}

A small amount of leaves' extract was mixed with $2 \mathrm{ml}$ of chloroform and $3 \mathrm{ml}$ of conc. $\mathrm{H}_{2} \mathrm{SO}_{4}$ carefully to make a layer of reddish-brown coloration, verifying the presence of terpenoids ${ }^{25}$.

\section{Anthraquinone:}

To check the presence of anthraquinones, leaves extract was boiled with $10 \mathrm{ml}$ of dil. $\mathrm{H}_{2} \mathrm{SO}_{4}$ and filtered while hot. To the filtrate, $5 \mathrm{ml}$ of chloroform was added further. The mixture was shaken and the chloroform layer was transferred into another test tube containing $1 \mathrm{ml}$ of dil. ammonia. The appearance of violet colour confirmed the presence of anthraquinine ${ }^{25}$.

\section{Preparation of Extract Solution For In Vitro Activity}

An equal volume of extract and distilled water were shaken vigorously and left overnight. The next day, the solution was filtered to be used for further activities ${ }^{26,27}$.

\section{Anti-Inflammatory Activity (In Vitro Study)}

\section{Human Red Blood Cell Suspension (HRBC) Preparation}

Blood $(5 \mathrm{ml})$ from healthy human volunteers, free from NSAID, was drawn in a tube containing heparin and centrifuged at $3000 \mathrm{rpm}$ for $10 \mathrm{~min}$. Plasma was discarded, and residual blood cells and RBCs ware washed three times with normal saline. Following this, $2 \%$ v/v suspension was prepared with normal saline for further use ${ }^{28,29}$.

\section{Hypotonicity Induced Hemolysis}

In each tube, $0.5 \mathrm{ml}$ of $2 \% \mathrm{HRBC}$ suspension and $0.5 \mathrm{ml}$ normal saline ( $\mathrm{NaCl} 0.03 \%$ ) was mixed. Later on, variable concentrations of leaf extract were added (i.e. 100$500 \mu \mathrm{l} / \mathrm{ml}$ ) in each tube. Control was prepared without extract. Furthermore, Diclofenac sodium injection (100, $200 \mathrm{\mu l} / \mathrm{ml}$ ) was added as a standard drug and tubes were incubated at $37^{\circ} \mathrm{C}$ for $30 \mathrm{~min}$ followed by centrifugation at $3000 \mathrm{rpm}$ for $10 \mathrm{~min}$. The supernatant was decanted, and hemoglobin content was estimated at $540 \mathrm{~nm}$ spectrophotometrically ${ }^{30,31}$. The $\%$ protection was calculated by using the formulas:

Hemolysis $\%=($ Abs of test sample/Abs of control $) \times 100$

Protection $\%=100-(\%$ hemolysis $)$

\section{RESULTS}

\section{Phytochemical evaluation}

Ethanolic extract of Calotropis procera leaves was subjected to check the presence of phytochemicals in it. The phytochemical evaluation depicted that flavonoids, alkaloids, tannins, terpenoid, saponins, steroids and 
cardiac glycosides were present but phlobatannins and anthraquinone were absent ${ }^{32}$ (Table 3 ).

Table 3. Phytochemical Analysis of Calotropis procera Leaves.

\begin{tabular}{ccc}
\hline S.No. & Phytochemicals & Result \\
\hline 01 & Tannins & + \\
\hline 02 & Alkaloid & ++ \\
\hline 03 & Terpenoid & ++ \\
\hline 04 & Flavonoid & ++ \\
\hline 05 & Saponins & + \\
\hline 06 & Phlobatannins & - \\
\hline 07 & Anthraquinone & - \\
\hline 08 & Steroids & + \\
\hline 09 & Cardiac Glycosides & + \\
\hline
\end{tabular}

$++=$ high amount, $+=$ less amount, $-=$ Absent

\section{Anti-inflammatory activity}

In vitro activity of ethanolic extract of Calotropis procera leaves was checked against $2 \%$ HRBC suspension. Results in Table 4 indicated that the concentrations of extract $(100,200 \mu \mathrm{l} / \mathrm{ml})$ did not show significant membranestabilizing effect whereas, the concentration ranges of $(300-500 \mu / / m l)$ presented significant stabilization with maximum protection around $73.11 \%$ at $500 \mu \mathrm{l} / \mathrm{ml}$, whereas, standard diclofenac sodium showed $67.24 \%$ stabilization at $200 \mu \mathrm{l} / \mathrm{ml}$.

Table 4 \& Fig. 1 shows \% protection of ethanolic extract Calotropis procera leaves against hypotonicity induced hemolysis on $2 \% \mathrm{HRBC}$ suspension.

Table 4. Percentage Protection of Calotropis procera Leaves on $2 \%$ HRBC Suspension by Hypotonicity Induced Hemolysis.

\begin{tabular}{cccccc}
\hline S.No. & Treatment(s) & $\begin{array}{c}\text { Concentrations } \\
(\boldsymbol{\mu l} / \mathbf{m l})\end{array}$ & $\begin{array}{c}\text { Absorbance } \\
(\mathbf{A})\end{array}$ & $\begin{array}{c}\text { Heamolysis } \\
(\%)\end{array}$ & $\begin{array}{c}\text { Protection } \\
(\%)\end{array}$ \\
\hline 01 & Control & - & $1.056 \pm 0.18$ & - & - \\
\hline 02 & ECPL & 100 & $0.668 \pm 0.02$ & 63.25 & 36.75 \\
\hline 03 & ECPL & 200 & $0.577 \pm 0.03$ & 54.64 & 45.36 \\
\hline 04 & ECPL & 300 & $0.429 \pm 0.03$ & 40.62 & 59.38 \\
\hline 05 & ECPL & 400 & $0.343 \pm 0.01$ & 32.48 & 67.52 \\
\hline 06 & ECPL & 500 & $0.284 \pm 0.01$ & 26.89 & 73.11 \\
\hline 07 & DS & 100 & $0.561 \pm 0.01$ & 48.39 & 51.61 \\
\hline 08 & DS & 200 & $0.346 \pm 0.01$ & 32.76 & 67.24 \\
\hline
\end{tabular}

Each value is shown in mean $\pm \mathrm{SD}$, Here $\mathrm{ECPL}=$ Extract of Calotropis procera leaves, $\mathrm{DS}=$ Diclofenac sodium

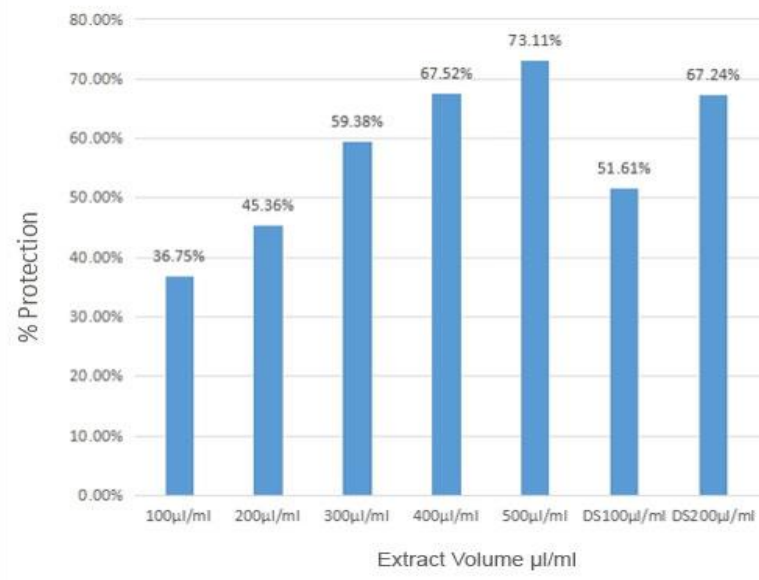

Figure 1. \% protection of Calotropis procera against $2 \% \mathrm{HRBC}$ suspension. 


\section{DISCUSSION}

Medicinal plants contain many phytochemicals that are responsible for the treatment of different diseases. Anciently, men used medicinal plants due to their therapeutic potential, which facilitated them to cure diseases. Nature has given us medicinal plants which have medicinal values ${ }^{33}$.

In the current study, there were many phytochemicals detected from ethanolic extract of Calotropis procera leaves by general identification methods, which showed therapeutic potential.

For checking the therapeutic potential of ethanolic extract of Calotropis procera leaves, we used in vitro antiinflammatory activity by HRBC erythrocyte membrane stabilization method. The principle behind this method is that when Red Blood Cells (RBCs) get exposure to substances such as hypotonic medium, heat etc., lysis of membrane take place ${ }^{34,35}$. These erythrocyte membranes are analogous to the lysosomal membranes and their stabilization implies that the extract may well stabilize the lysosomal membrane.

The present work revealed that the ethanolic extract of Calotropis procera leaves has potential against inflammation of the erythrocyte membrane. The activity was increased by increasing the extract dose. 100 $\mathrm{\mu} / \mathrm{ml}$ and $200 \mathrm{\mu l} / \mathrm{ml}$ showed non-significant efficacy such as $36.75 \%$ and $45.36 \%$, respectively. The extract dose $300 \mu \mathrm{l} / \mathrm{ml}$ and $400 \mu \mathrm{l} / \mathrm{ml}$ showed significant efficacy such as $59.38 \%$ and $67.52 \%$, respectively. The extract dose $500 \mu / \mathrm{ml}$ showed greater efficacy of $73.11 \%$ than the standard Diclofenac sodium $100 \mu \mathrm{l} / \mathrm{ml}$ and $200 \mu \mathrm{l} / \mathrm{ml}$ which showed $51.61 \%$ and $67.24 \%$, respectively. The results were also indicated graphically in the figure 1.

\section{CONCLUSION}

It is concluded that the ethanolic extract of Calotropis procera leaves have the potential to cure inflammatory diseases and can be used as anti-inflammatory and analgesic medicine.

\section{ACKNOWLEDGEMENTS}

I am very thankful to my supervisor Mr Naveed Aslam Dogar and Mr. Farooq Saleem for their guidance and support in this research work.

\section{LIST OF ABBREVIATION}

DS Diclofenac Sodium

ECPL Extract of Calotropis procera Leaves

HRBCs Human Red Blood Cells

NSAIDs Non-Steroidal Anti-Inflammatory Drugs

\section{REFERENCES}

1. Modak M, Dixit P, Londhe J, Ghaskadbi S, Devasagayam TP. Recent advances in Indian herbal drug research guest editor: Thomas Paul Asir Devasagayam Indian herbs and herbal drugs used for the treatment of diabetes. J Clin Biochem Nutr. 2007; 40(3):163-73.

2. Satyavati, G.V., Gupta AK, Tandon N. Med Plants of India, ICMR. 1987. P. 16. 2.

3. Zhang Q, Sharan A, Espinosa SA, Gallego-Perez D, Weeks J. The path toward integration of traditional and complementary medicine into health systems globally: The World Health Organization report on the implementation of the 2014-2023 strategy. J Altern Complement Med. 2019; 25(9):869-71.

4. Mossa JS, Tariq M, Mohsin A, Ageel AM, Al-Yahya MA, Al-Said MS, Rafatullah S. Pharmacological studies on aerial parts of Calotropis procera. Am J Chinese Med. 1991; 19(04):223-31.

5. Sholapur HN, Patil BM. Effect of Moringa oleifera bark extracts on dexamethasone-induced insulin resistance in rats. Drug Res. 2013; 63(10):527-31.

6. Yogi B, Gupta SK, Mishra A. Calotropis procera (Madar): A medicinal plant of various therapeutic uses-A review. Bull Env Pharmacol Life Sci. 2016; 5(7):74-81.

7. Chatterjee A, Parkashi S. The treatise of Indian medicinal plants, volume IV. New Delhi: Publication and Information Directorate CSIR. 1995.

8. Kabir H, Naz A, Khan NA. Unani medicinal plants in Hamdard University campus, India. Hamdard Medicus (Pakistan). 2003; 1:34-40.

9. Verma R, Satsangi GP, Shrivastava JN. Ethnomedicinal profile of different plant parts of Clotropis procera (Alt.) R Br Ethnobotanical Leaflets. 2010; 14:721-42.

10. Bhaskar VH, Ajay SS. Evaluation of antihperglycemic activity of extracts of Calotropis procera (Ait.) $\mathrm{R}$. Br on streptozotocin induced diabetic rats. Glob J Pharmacol. 2009; 3(2):95-8.

11. Sen SK, Behra LM. Ethnomedicinal plants used in touch therapy at Bargarh district of Orissa. Ethnobot. 2007; 19(1\&2):100-04.

12. Anis M, Sharma MP, Muhammad I, Herral. Ethnomedicine for the Gwalier forest division in Madhya Pradesh, India. Pharm Biol. 2007; 38(4): 241-53. 
13. Evans WC. Trease and Evans, Pharmacognosy 2005; 41-7.

14. Ragunathan M, Abay SM. Ethnomedicinal survey of folk drugs used in Bahirdar Zuria district, Northwestern Ethiopia. 2009; 8(2):281-4.

15. Azhar MF, Siddiqui MT, Ishaque M, Tanveer A. Study of ethnobotany and indigenous use of Calotropis procera (Ait.) in cholistan desert, Punjab, Pakistan. J Agric Res. 2014; 52(1):117-26.

16. Roy S, Sehgal R, Padhy BM, Kumar VL. Antioxidant and protective effect of latex of Calotropis procera against alloxan-induced diabetes in rats. J Ethnopharmacol. 2005; 102(3): 470-3.

17. Setty SR, Quereshi AA, Swamy AV, Patil T, Prakash T, Prabhu K, Gouda AV. Hepatoprotective activity of Calotropis procera flowers against paracetamolinduced hepatic injury in rats. Fitoterapia. 2007; 78(78):451-4.

18. Van Quaquebeke E, Simon G, André A, Dewelle J, Yazidi ME, Bruyneel F, Tuti J, Nacoulma O, Guissou $\mathrm{P}$, Decaestecker C, Braekman JC. Identification of a Novel Cardenolide (2"-Oxovoruscharin) from Calotropis procera and the hemisynthesis of novel derivatives displaying potent in vitro antitumor activities and high in vivo tolerance: Structure- activity relationship analyses. J Med Chem. 2005; 48(3):84956.

19. Mossa JS, Tariq M, Mohsin A, Ageel AM, Al-Yahya MA, Al-Said MS, Rafatullah S. Pharmacological studies on aerial parts of Calotropis procera. Am J Chinese Med. 1991; 19(04):223-31.

20. Yesmin N, Nasir Uddin S, Mubassara S, Ali Ako M.Antioxidant and Antibacterial Activities of Calotropis procera Linn AM Eurasian J Agric Environ Sci. 2008; 4(5):550-3.

21. Sharma P, Sharma JD. Evaluation of in vitro schizontocidal activity of plant parts of Calotropis procera-An ethnobotanical approach. J Ethnopharmacol. 1999; 68(1-3):83-95.

22. Sharma $P$, Sharma JD. In vitro schizonticidal screening of Calotropis procera. Fitoterapia. 2000; 71(1):77-9.

23. Ranjit PM, Santhipriya T, Nagasri S. Phytochemical screening and anti-bacterial activities of ethanolic extract of flower against human pathogenic strains. AJPCR 2012; 74(5): 443-50.

24. Gajare SM, Patil MV, Mahajan RT. Phytochemical screening and antimicrobial activity of ethanol extract of Calotropis procera root. IJRPP. 2012; 2(3):143-6.
25. Kumar S, Sharma UK, Sharma AK, Pandey AK. Protective efficacy of Solanum xanthocarpum root extracts against free radical damage: Phytochemical analysis and antioxidant effect. Cell Mol Biol. 2012; 58(1):171-8.

26. Prasad S, Kashyap RS, Deopujari JY, Purohit HJ, Taori GM, Daginawala HF. Effect of Fagonia arabica (Dhamasa) on in vitro thrombolysis. BMC Complem Altern M. 2007; 7(1):1-6.

27. Amri O, Zekhnini A, Bouhaimi A, Tahrouch S, Hatimi A. Anti-inflammatory activity of methanolic extract from Pistacia atlantica desf. leaves. Pharmacog J. 2018; 10(1):71-76.

28. Sakat S, Juvekar AR, Gambhire MN. In vitro antioxidant and anti-inflammatory activity of methanol extract of Oxalis corniculata Linn. Int J Pharm Pharm Sci. 2010; 2(1):146-55.

29. Sadique J, Al-Rqobahs WA, Bughaith El, Gindi AR. The bioactivity of certain medicinal plants on the stabilization of RBC membrane system. Fitoterapia. 1989; 60(6):525-32.

30. Dima J, Raghda L, Jalil GA. Evaluation of hemolytic and anti-hemolytic activity of the aerial parts of Sonchus oleraceus extracts. Int J Pharm Sci Nanotechnol. 2017; 10(3):3745-51.

31. Azeem AK, Dilip C, Prasanth SS, Shahima VJ, Sajeev $\mathrm{K}$, Naseera C. Anti-inflammatory activity of the glandular extracts of Thunnus alalunga. Asian Pac J Trop Med. 2010; 3(10):794-6.

32. Shamim SA, Fatima L. Pharmacological actions and therapeutic uses of Aak (Calotropis procera): A Review. J Pharm Innov. 2019; 8(2): 40-7.

33. Heidarian $E$, Jafari-Dehkordi $E$, Valipour $P$, GhatrehSamani K, Ashrafi-Eshkaftaki L. Nephroprotective and anti-inflammatory effects of Pistacia atlantica leaf hydroethanolic extract against gentamicin-induced nephrotoxicity in rats. J Diet Suppl. 2017; 14(5):489502.

34. Debnath PC, Das A, Islam A, Islam MA, Hassan MM, Uddin SM. Membrane stabilization-A possible mechanism of action for the anti-inflammatory activity of a Bangladeshi medicinal plant: Erioglossum rubiginosum (Bara Harina). Pharmacog J. 2013; 5(3):104-7.

35. Bhatti GR, Qureshi R, Shah SM. Ethnobotany of Calotropis procera with special reference to the people of Nara Desert. Scientific Sindh Ann J Res. 1998; 5:1322. 